\title{
Deleterious effects of prepubertal corticosterone treatment on rat prostate ${ }^{1}$
}

\author{
Flávia Cristina Morone PintoI, Dílson Silva ${ }^{I I}$, Pamella Campos Silva ${ }^{I I I}$, Luiza Morone Pereira ${ }^{\mathrm{IV}}$, Arlene Regina Morone \\ Waldemar Silva Costa ${ }^{\mathrm{VI}}$, Célia Martins Cortez ${ }^{\mathrm{VII}}$, Francisco José Barcellos Sampaio ${ }^{\mathrm{VIII}}$
}

DOI: http://dx.doi.org/10.1590/S0102-865020150060000002

IAssistant Professor and Researcher for Experimental Surgery, Department of Surgery, Center for Health Sciences, Federal University of Pernambuco (UFPE), Recife-PE, Brazil. Technical procedures, histomorphometrical examination, statistical analysis, manuscript writing.

IIResearcher, Department of Applied Mathematics, State University of Rio de Janeiro (UERJ), Rio de Janeiro-RJ, Brazil. Design of the study, supervised all phases of the manuscript, critical revision.

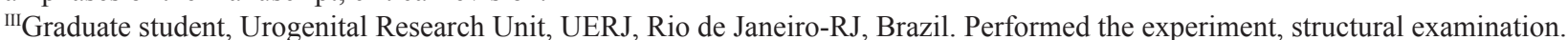

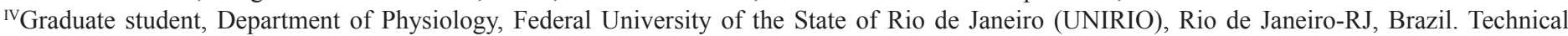
procedures, functional examination.

vAssistant Professor, Department of Physiology, UNIRIO, Rio de Janeiro-RJ, Brazil. Technical procedures, functional examination, supervised all phases of the manuscript, critical revision.

${ }^{\mathrm{V}}$ Associate Professor, Urogenital Research Unit, UERJ, Rio de Janeiro-RJ, Brazil. Design of the study, supervised all phases of the experiment, manuscript writing.

${ }^{\mathrm{VII}}$ Associate Professor, Department of Applied Mathematics, Postgraduate Program in Computer Science, Physical Modeling Group in Mathematical Biology, UERJ, Rio de Janeiro-RJ, Brazil. Design of the study, supervised all phases of the experiment, manuscript writing, critical revision.

VIIIFull Professor, CNPq 1A Researcher, Urogenital Research Unit, UERJ, Rio de Janeiro-RJ, Brazil. Scientific and intellectual content of the study.

\section{ABSTRACT}

PURPOSE: To investigate the structural and functional changes induced by corticosterone (CORT) in the ventral prostrate (VP) of rats in order to study chronic stress effects in the prepubertal phase.

METHODS: Wistar rats received daily saline or CORT injections during the pubertal period from the 5th to 25 th day of postnatal life. The animals were distributed into four groups: 1 - Control $(n=5) ; 2$ - Control 99mTc-P (n=5); 3 - Treated with CORT (n=14); 4 - Treated with CORT and 99mTc-P $(n=10)$. All rats were sacrificed at two months of age. Technical tissue uptakes of $99 \mathrm{mTc}-\mathrm{P}$ were used to evaluate the functional and stereological methods for morphological analysis.

RESULTS: Acini distribution in the group treated with CORT differed significantly $(\mathrm{p}<0.0001)$ from the control. The control group's epithelial average height $(10.01 \pm 0.24$ microns $)$ was statistically significant $(p<0.0001)$ from rats treated with CORT $(19.27 \pm 0.73 \mathrm{microns})$. The collagen distribution was lower in the treated group (2.79\%) when compared to control (3.97\%). The radioactivity percentage in the groups marked with $99 \mathrm{mTc}-\mathrm{P}(\% \mathrm{Ati} / \mathrm{g})$ did not demonstrate a statistically significant difference $(\mathrm{p}=0.285897)$.

CONCLUSION: Chronic administration of corticosterone in prepubertal rats causes changes in their acinar structure and their ventral prostate stroma, indicating possible deleterious effects of this hormone.

Key words: Corticosterone. Glucocorticoids. Prostate. Anatomy \& Histology. Rats. 


\section{Introduction}

Glucocorticoids (GC), produced by the adrenal cortex regulate the metabolism of carbohydrates and hemodynamic functions, and play an important role in physiological regulation and adaptation to stressful situations. Most of the effects are mediated by the glucocorticoid receptors and are essential to life ${ }^{1}$. Although high levels of glucocorticoids are essential in an acute reaction to stress, chronically increased levels may have unwanted effects $^{2,3}$.

In prenatal and pubertal stages, GCs help sex hormones in the formation and maturation of the genitals. However, at increased levels, GCs tend to inhibit hormone secretion ${ }^{4}$. Clinical and experimental studies have shown adverse effects of excess GC on testicular testosterone production ${ }^{5}$.

The prostate is the only accessory sex gland found in all mammalian species but may have appreciable morphological differences, even in closely related species within the same family. It is transversed by the urethra and the ejaculatory ducts, has a conical shape with the apex down, and surrounded by a capsule rich in blood vessels. In rats the prostate is not a compact structure, lobes are divided into functional parts (anterior lobe or coagulating gland, dorsal and the ventral lobe) on the basis of differing responsiveness of hormones of the glandular tissue located ventral to the urethra as compared to those situated dorsally ${ }^{6,7}$. Both human and rodent prostates are composed of glandular acini dispersed in a fibromuscular stroma with excretory ducts lined by epithelial cells, glandular myoepithelial cells, interstitial and subepithelial bullae ${ }^{8}$.

There is a possibility that Technetium-99m pertechnetate (Tc-99m) might be captured by the genital organs, concentrating in the fallopian tubes, kidneys, ovaries, testes, penis and possibly the prostate ${ }^{9,10}$. But there is no data in the literature comparing the uptake capacity for these organs.

This paper evaluates the structural and functional changes induced by corticosterone (CORT) in the ventral prostate (VP) of Wistar rats submitted to chronic stress effects in the prepubertal stage, using stereological methods and tissue uptake of 99mTc-P.

\section{Methods}

\section{Animal model and experimental design}

The experimental protocol was approved by the ethical committee of UERJ (CEA/250/2008), and follows the recommendations of the conventional guide to animal testing (Guide for the care and use of laboratory animals, 1996).
Virgin female Wistar rats (Rattus norvegicus albinus Wistar) mated for 24 hours. Copulation was confirmed the following morning by the presence of a vaginal plug. All animals were maintained in individual cages under controlled temperature conditions, humidity (ca. 70\%) and light-dark cycle (12 hours each), with free access to feed (Nuvital ${ }^{\circledR}$, Nuvilab Ltda., CuritibaPR, Brazil) and water ad libitum.

After pregnancy and during lactation, the animals were kept separated by brood in plastic cages covered with sawdust. Up to weaning, mothers remained in cages with their pups. Five days after birth, the pups were divided (by marks on the tail) into two groups. One group $(n=10)$ received daily injections of saline during the pubertal period, from the 5 th to the 25 th day of postnatal life, and the other $(n=24)$ in the same period, received daily intraperitoneal injection of CORT at a $2 \mathrm{mg} / 100 \mathrm{~g}$ body weight dose as suggested by the adapted protocol ${ }^{5}$. On the 25 th postnatal day, injections of CORT and saline were suspended. The evolution of animal body weight was monitored daily until sacrifice.

On the 60th day prior to sacrifice, five rats in the control group and 10 in the group treated with CORT were separated and each rat received $0.3 \mathrm{ml}$ of Na99mTcO4 (7.4 Mbq), Tc-99m pertechnetate (99mTcO4-) recently obtained from $99 \mathrm{Mo} / 99 \mathrm{mTc}$ in $0.9 \% \mathrm{NaCl}$ solution through the eye plexus. Thus, four groups were formed: Group 1 - Control $(\mathrm{n}=5)$; Group 2 - Control labeled with 99mTc-P ( $\mathrm{n}=5)$; Group 3 - Treated with CORT $(\mathrm{n}=14)$; Group 4 - treated with CORT and 99mTc-P $(n=10)$.

All rats were sacrificed after two months (60 days) by the forced inhalation of carbon dioxide $\left(\mathrm{CO}_{2}\right)$ and a fraction of blood was collected from each by cardiac puncture.

\section{Stereological analysis}

Using a stereoscopic microscope (DF Vasconcelos ${ }^{\circledR}$ SA, Sao Paulo, Brazil), we immediately extracted the prostates from all the rats in groups 1 and 3. These were weighed and fixed ( $1.27 \mathrm{~mol} / 1$ formaldehyde in $0.1 \mathrm{M}$ phosphate buffer, $\mathrm{pH} 7.2)$. The material was dissected following laboratory histological routine.

The following were analyzed: number of acini, area of the acini, and height of the epithelium of the prostate acini. In all analyses, were used section thicknesses of $5 \mathrm{~mm}$, stained with hematoxylin and eosin (HE). For the morphometric analysis of collagen density, $5 \mathrm{~mm}$ thick sections, stained with Sirius Red Picro without bias were also used.

The images were captured using Image pro-Express ${ }^{\circledR}$ (1993-2004 Media Cybernetics, Inc., version 5.0) and processed using Adobe Photoshop 6.0 ${ }^{\circledR}$ (Technique Computed 
Histofotometria) $)^{11}$. The Image $\mathbf{J}^{\circledR}$ program (Image Processing and Analysis in Java, version 1:37, National Institutes of Health, USA) was used for analysis of the captured images.

The sections were examined using an optical microscope (BX51 - Olympus, Japan) and images were captured using a camera (DP70 - Olympus, Japan) connected to monitor (LG Flatron, Brazil). As for the area, the acini were classified according to to size using this criteria: small (S), the area between 100 and $10.000 \mu \mathrm{m}^{2}$; Medium (M), the area between 10.000 and 100.000 $\mu \mathrm{m}^{2}$; and large (L) $\mu \mathrm{m}^{2}$ area above 100.000 .

\section{Study of uptake of Technetium (Tc-99mpertechnetate)}

The animals in groups 2 and 4 were sacrificed 10 minutes after an injection of $\mathrm{Na99mTcO} 4$ (7.4 Mbq) obtained from the Institute of Energy and Nuclear Research, National Nuclear Energy Commission, Brazil. The radioactivity was measured in a gamma counter NaI (TI) (Cobra Auto-gamma, Packard Instrument Co. Downers Grove, Illinois, USA). The percentage of activity per gram $(\% \mathrm{ATI} / \mathrm{g})$ and the $\mathrm{Na} 99 \mathrm{mTcO} 4$ injected dose per gram of tissue $(\%$ $\mathrm{ID} / \mathrm{g}$ ) were determined.

\section{Statistical analysis}

For data adjusted to the normal curve, the Student $\mathrm{t}$ test was used. The Mann-Whitney test was used to analyze non-parametric data. The chi-square test was used to determine proportions and percentages. All differences were considered statistically significant when $\mathrm{p}<0.05$. Statistical calculations were performed with the GraphPad PRISM ${ }^{\circledR}$ program (Prism 5 for Windows, version 5.00, March, 2007. GraphPad Software, Inc.).

\section{Results}

An analysis of animal body mass data from the 5 th to the 60th day found no significant difference $(p=0.3226)$ in body weight gain in rats treated with CORT (Groups 3 and 4) and control (groups 1 and 2). In the period of treatment (from the 5 th to the 25 th day) weight gain differences were not significant $(\mathrm{p}=0.8493)$. There was no significant prostate weight difference $(p=0.5648)$ between the average weights of the rats treated $(1.08 \pm 0.20 \mathrm{~g})$ and untreated $(1.03 \pm 0,09 \mathrm{~g})$ with CORT (Table 1).

TABLE 1 - Body weight gain among the groups.

\begin{tabular}{lccccc}
\hline \multirow{2}{*}{ Weight (g) } & \multicolumn{2}{c}{ Control } & \multicolumn{2}{c}{ Treated } & Groalue \\
\cline { 2 - 6 } & Group 1 & Group 2 & Group 3 & Group 4 \\
\hline $25^{\text {th }}$ day & $39.19 \mathrm{~g} \pm 2.57$ & $33.2 \mathrm{~g} \pm 2.9$ & $39.54 \mathrm{~g} \pm 3.79$ & $33.4 \mathrm{~g} \pm 4.6$ & 0.8493 \\
$60^{\text {th }}$ day & $268.11 \mathrm{~g} \pm 50.38$ & $268.8 \pm 24.1$ & $243.03 \mathrm{~g} \pm 46.25$ & $268.9 \pm 41.2$ & 0.3226 \\
\hline
\end{tabular}

Values represent the mean \pm standard deviation (SD). In all analyzes, the difference was considered statistically significant when $\mathrm{p}<0.05$.

The acini distribution (\%) by size (small, medium and large) in the group treated with CORT differed significantly $(p<0.0001)$ compared to the control. In the control group, the growth percentages of the small acini (18.24\%) and large (31.76\%) were higher than in CORT $(0.57 \%$ small acinar and $18.00 \%$ of large acini). Medium acini were higher in the treated rats $(81.43 \%)$ than in the control (50.00\%) (Table 2, Figures $1 \mathrm{~A}$ and B).

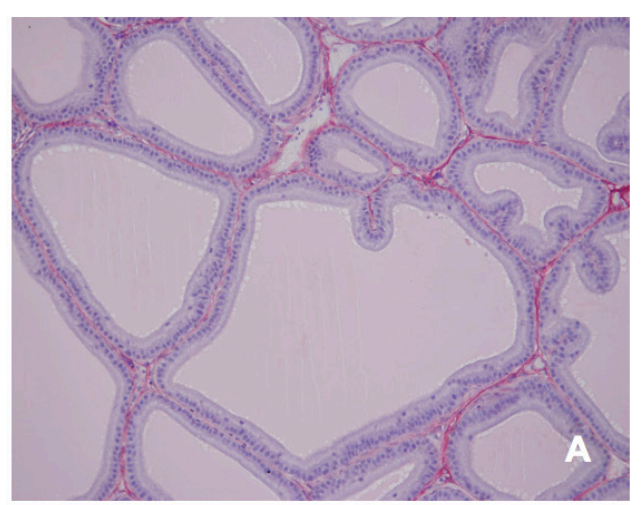

The epithelial average height $(10.01 \pm 0.24$ microns $)$ of the control group was statistically more significant $(\mathrm{p}<0.0001)$ than in rats treated with CORT $(19.27 \pm 0.73$ microns) (Table 2).

The collagen distribution was lower in the treated group (2.79\%) when compared to control (3.97\%) but was not considered significantly different $(\mathrm{p}=0.1746)$ (Table 2$)$.

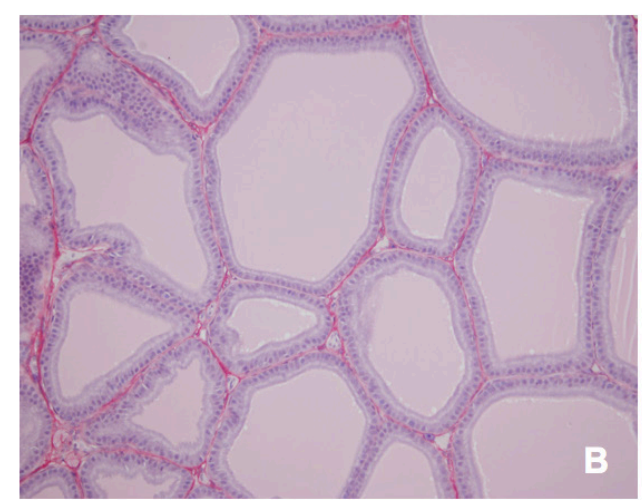

FIGURE 1 - Photomicrograph illustrating the structure of prostate acini. A. Control group; B. Treated group. [HE, x200] 
TABLE 2 - Morphometric aspects.

\begin{tabular}{|c|c|c|c|c|c|c|c|c|}
\hline \multirow[t]{2}{*}{ Groups } & \multicolumn{3}{|c|}{ Distribution of acini by size (\%) } & \multicolumn{3}{|c|}{ Area of acini $\left(\mu m^{2}\right)$} & \multirow{2}{*}{$\begin{array}{c}\text { Height of the } \\
\text { epithelium }(\mu \mathrm{m})\end{array}$} & \multirow{2}{*}{$\begin{array}{c}\text { Distribution of } \\
\text { collagen }(\%)\end{array}$} \\
\hline & $\mathbf{S}$ & $\mathbf{M}$ & $\mathbf{L}$ & $\mathbf{S}$ & M & $\mathbf{L}$ & & \\
\hline $\begin{array}{l}\text { Control } \\
\text { (group } 1 \text { and } 2 \text { ) }\end{array}$ & 18.24 & 50.00 & 31.76 & 4,510 & 63,150 & 241,300 & $19.27 \pm 0.73$ & 3.97 \\
\hline $\begin{array}{c}\text { Treated } \\
\text { (group } 3 \text { and 4) }\end{array}$ & $0.57^{\mathrm{a}}$ & $81.43^{\mathrm{a}}$ & $18.00^{\mathrm{a}}$ & 6,614 & 63,610 & $152,500^{\mathrm{a}}$ & $10.01 \pm 0.24^{\mathrm{a}}$ & 2.79 \\
\hline $\mathrm{p}$-value & & $<0.0001$ & & $=0.0613$ & $=0.8369$ & $<0.0001$ & $\mathrm{p}<0.0001$ & $p=0.1746$ \\
\hline
\end{tabular}

Size using this criteria: small (S); Medium (M); large (L). Data are expressed as mean \pm SD and percentages (\%). For percentage values Chi-square was applied. Student $\mathrm{t}$ test was performed for analysis of acinar epithelial height and area. Wilcoxon signed rank test was used to determine distribution of collagen. For the analysis of Tissue Uptake of $99 \mathrm{mTc}-\mathrm{P}$, ANOVA and multiple comparisons of Tukey-Kramer were used. In all analyses, the difference was considered statistically significant when $\mathrm{p}<0.05$, $\mathrm{a} \neq$ control.

The radioactivity percentage in the groups marked with 99mTc-P (\% Ati/g) was $0.938917 \pm 0.392149 \%$ Ati $/ g$ for Group 2 and $0.805935 \pm 0.455481 \%$ Ati/g for Group 4, showing no statistically significant difference $(p=0.285897)$.

\section{Discussion}

GCs are widely used in prostate cancer treatment owing to their palliative effects. Reported effects are linked to decreased prostate specific antigen levels and amelioration of symptoms ${ }^{12}$. However, there is little information in the literature about normal $\mathrm{CG}$ effects on the prostate.

The present study found an approximately $10 \%$ body weight decrease in the group treated with CORT (Table 1), compared to the control, from the 5th to the 60th postnatal day, but this difference was not considered significant.

Acute treatment of rats with dexamethasone (Decadron, intraperitoneally $1 \mathrm{mg} / \mathrm{kg}$ body weight for five days) was able to reduce animal body weight significantly ${ }^{13}$. However, dexamethasone is a synthetic corticosteroid with a glucocorticoid effect much higher ( $>25$ fold) than that observed with cortisol and CORT $^{14,15}$.

In contrast to these results, in a previous study, the mean body weight of rats increased during daily treatment with cortisol $(1 \mathrm{mg} / \mathrm{kg} /$ day) administered from the 8 th to the 36 th day of postuterine life ${ }^{16}$. The authors attributed the increase of the cortisol to mineralocorticoid effect, which causes renal retention of $\mathrm{Na}^{+}$ and $\mathrm{K}^{+}$loss when chronically administered in high doses, resulting in water retention. The corticosterone in rats regulates energy metabolism and stress responses, similar to cortisol effects on the human body. Cortisol is about $95 \%$ of the GC content secreted by human adrenal glands, while CORT is almost $100 \%$ of the content in $\operatorname{rats}^{17,18}$.

The main factor responsible for the body weight decrease which accompanied the dexamethasone treatment would be the serum insulin increase ${ }^{13}$. Previously, some authors ${ }^{19,20}$ have suggested that insulin resistance could be the explanation for body weight reduction in rats treated with CORT.

Recently this effect has been attributed to lower feed intake, motivating a decrease of approximately 30\% in body weight compared to control, accompanying the chronic high dose treatment with CORT. This hypothesis has been already raised in previous studies ${ }^{21}$.

Suggestions that GC chronic treatment is behind weight loss corroborate each other, since insulin acts in the hypothalamus to regulate the activity of some neuropeptides involved in food intake control, maybe being an indirect mechanism of CORT action on body weight ${ }^{13}$.

One hypothesis concerning the lack of significant data relative to the control, given the body weight of the animals in our research, contrasting with other works, is that the dose of CORT administered was not high enough to cause notable metabolic changes, besides the fact that CORT is much less powerful than dexamethasone.

Although no significant differences were found in the weight of rat prostates, those treated compared to control, the prostate structure analysis showed a significant difference $(\mathrm{p}<0.0001)$ in acini distribution of treated group compared to control. The acini classified as large (Table 2) in the treated group showed a reduction size of about $37 \%\left(152.500 \mu \mathrm{m}^{2}\right)$ compared to the control $\left(241.300 \mu \mathrm{m}^{2}\right)$. Furthermore, a significant reduction in acinar epithelium height (Table 2) was observed in the group receiving $\mathrm{CG}$, confirming other literature results. Dexamethasone treatment was observed to lead to atrophy and decreased proliferative activity of epithelial cells of the prostate ${ }^{13}$.

For collagen distribution (Table 2), the group treated with CORT had a reduction, which can be associated with the action of GC on ECM (Extracellular Matrix), especially on fibroblasts. Morphological alterations were observed in stromal cells caused by GC activity, suggesting the activation of fibroblasts and atrophy 
of smooth muscle cells ${ }^{13}$. Consistent with that hypothesis, another study shows a decrease in the order of $43 \%$ and $80 \%$ in the formation of collagen gel in human fibroblast cultures that had received dexamethasone and cortisol, respectively ${ }^{22}$.

The collagen is known to be one of the most active components in the modulation of biological activities occurring in the ECM. Therefore, an appropriate balance between synthesis and degradation is required for normal tissue functioning. Improper balance, both quantitative and qualitative, can produce a decrease in compliance of the injured tissue, causing functional changes and therefore clinical problems.

The normal development of the VP rat goes through three distinct phases: (1) the initial growth within the first three weeks, (2) at rest and (3) the pubertal growth, the latter being coincident with the rise in testosterone plasma. Thus, the postnatal VP growth results from a combination of epithelial proliferation and / or differentiation and the synthesis and / or accumulation of secretory products into the lumen ${ }^{23}$.

The prostate is sensitive to androgen action, which plays a key role in the metabolism and functioning of this gland. Testosterone influences glandular epithelium which converts to dihydrotestosterone (DHT) in the secretory cells of the glandular epithelium. DHT is about 30 times more potent than testosterone in this activity. Because of the functional testosterone dependence on it, deprivation of this hormone results in marked decline in the gland, with loss of epithelial cells by apoptosis and a prominent reorganization of the $\mathrm{ECM}^{24-25}$.

As already mentioned one of the effects of an excess of $\mathrm{GC}$ is testosterone secretion reduction. Independent of any direct GC effect on the prostatic epithelium, it has an indirect effect on the testosterone.

Alterations observed in the epithelium and the remaining collagen synthesis on the 20th day after the end of treatment with CORT may indicate danger to the regenerative capacity, and contractile prostate tissue function which would have been established during the pubertal phase.

The significant increase in medium acini with CORT treatment appears to have occurred mainly at expense of the number of small acini, although the order of the charge by size of the lobes has not changed: number of medium acini>large $>$ small. This significant reduction of small and large acini may also indicate less ability to rebuild tissue and functional changes of the acinar epithelium.

Prostate epithelial cells produce enzymes, including prostate specific antigen (PSA), prostatic acid phosphatase (regulates cell growth and metabolism of the prosthetic glandular epithelium) and fibrolisina (increases the fluidity of the semen) ${ }^{8}$. The prostatic secretion makes up $70 \%$ of semen volume and an important function of this discharge is due to its high bicarbonate content, which confers an alkali content, capable of neutralizing the acidic vaginal environment, making it hospitable to spermatozoa ${ }^{26}$.

The analysis of prostate function was performed by tissue activity of $99 \mathrm{mTc}-\mathrm{P}$. There are no previous reports using this radioisotope for this assessment after GC administration. The tissue radioactivity measurements showed that CORT decreased the tumor uptake of $99 \mathrm{~m}$ Tc-P. This result contributes to the hypothesis that the prostatic secretory function decreases with chronic GC administration, although it was not possible to measure the significance of this change, owing to inaccuracy of the valuation at $99 \mathrm{mTc}-\mathrm{P}$ radioisotope.

\section{Conclusion}

The chronic administration of corticosterone in prepubertal Wistar rats results in changes in their acinar structure and stroma of the ventral prostate, indicating a possible functional impairment of this gland in adulthood.

\section{References}

1. Faria CDC, Longui CA. Aspectos moleculares da sensibilidade aos glicocorticóides. Arq Bras Endocrinol Metab. 2006;50:983-95. doi: org/10.1590/S0004-27302006000600003.

2. Dinan TC. Glucocorticoids and the genesis of depression illness. A psychological model. $\mathrm{Br} J$ Psychiatry. 1994;164:265-371. doi: org/10.1192/bjp.164.3.365.

3. Alheira FV, Brasil MAA. Glicocorticóides e sintomas de humor. Rev Psiquiatr RS. 2005;27:177-86. doi: org/10.1590/S010181082005000200008 .

4. Cortez CM, Cruz FAO, Silva D. Psychological and physiological responses to stress: a review based on results from PET and MRI studies. Braz Arch Biol Tech. 2008;51:7-12. doi: org/10.1590/ S1516-89132008000700003.

5. Kavitha TS, Parthasarathy C, Sivakumar R, Badrinarayanan R, Balasubramanian K. Effects of excess corticosterone on NADPH generating enzymes and glucose oxidation in Leydig cells of adult rats. Hum Exp Toxicol. 2006;25:119-25. doi: org/10.1191/0960327 106ht591oa.

6. Roy-Burman P, Wu H, Powell WC, Hagenkord J, Cohen MB. Genetically defined mouse models that mimic natural aspects of human prostate cancer development. Endocr Relat Cancer. 2004;11:225-54. doi: org/10.1677/erc.0.0110225.

7. Taboga SR, Vilamaior, PSLe, Góes RM. Modulação androgênica e estrogênica na próstata: uma abordagem em modelos experimentais de roedores com enfoque na biologia estrutural. Arq Bras Endocrinol Metab. 2009;53:946-55. doi: org/10.1590/S000427302009000800007.

8. Shappell AB, Thomas GV, Roberts RL, HerberT R, Ittmann MM, Rubin ma, Humphrey PA, Sundberg JP, Rozengurt N, Barrios R, Ward JM, Cardiff RD. Prostate pathology of genetically engineered mice: definitions and classification. The Consensus Report 
from the Bar Harbor Meeting of the Mouse Models of Human cancer consortium prostate pathology committee. Cancer Res. 2004;64:2270-305. doi: org/10.1158/0008-5472.CAN-03-0946.

9. Olguner M, Akgur FM, Api A, Özer E, Aktug T. Urinary trypsin inhibitor present in fetal urine prevents intraamniotic meconiuminduced intestinal damage in gastroschisis. J Pediatr Surg. 2000;35:458-61. doi: org/10.1016/j.jpedsurg.2006.04.016.

10. Fait A, Ferioli A, Barbieri F. Organotin compounds. Toxicology. 1994;91:77-82. doi: org/10.1016/0300-483X(94)90244-5.

11. Oberholzer M, Östreicher M, Christen h, Brühlmann M. Methods in quantitative image analysis. Histochem Cell Biol. 1996;105:333-55. doi: org/10.1007/BF01463655.

12. Saika T, Kusaka N, Tsushima T, Yamato T, Ohashi T, Suyama B, Arata R, Nasu Y, Kumon H. Treatment of androgen-independent prostate cancer with dexamethasone: a prospective study in stage D2 patients. Okayama Urological Cancer Collaborating Group. Int J Urol. 2001;8:290-4. doi: org/10.1046/j.1442-2042.2001.00302.x.

13. Ribeiro DL, Rafacho A, Bosqueiro JR, Taboga SR, Goes RM. Cellular changes in the prostatic stroma of glucocorticoid-treated rats. Cell Tissue Rev. 2008;332:499-508. doi: org/10.1007/s00441008-0581-0.

14. Severino C, Brizzi P, Solinas A, Secchi G, Maioli M, Tonolo G. Low-dose dexamethasone in the rat: a model to study insulin resistance. Am J Physiol. 2002;283:E 367-73. doi: org/10.1152/ ajpendo.00185.2001.

15. Castro M. Efeitos Anti-inflamatórios e antiproliferativos dos glicocorticóides: concordância ou discordância? Arq Bras Endocrinol Metab. 2005;49:334-6. doi: org/10.1590/S000427302005000300001

16. Cortez CM, Costa WS, Babinski MA, Chagas MA. Morphometrical and stereological analysis of the superior cervical glanglion of Rattus norvegicus submitted to chronic treatment with cortisol. Int J Morphology. 2003;21:211-26. doi: org/10.4067/S071795022003000300006

17. Siswanto H, Hau J, Carlsson H-E, Goldkuhl R, Abelson KSP. Corticosterone concentrations in blood and excretion in faeces after ACTH administration in male Sprague-Dawley rats. In vivo. 2008;22:435-40. doi: org/10.1055/s-2007-1010830.

18. Kozlov VM, Solenov EI, Ivanova LN. Changes in the content of glucocorticoids in the plasma and tissues of rats in postnatal ontogeny. Probl Endokrinol (Mosk). 1990;36:66-9. PMID: 2362931.

19. Barbera M, Fierabracci V, Novelli M, Bombara M, Masiello P, Bergamini E, De Tata V. Dexamethasone-induced insulin resistance and pancreatic adaptive response in ageing rats are not modified by oral vanadyl sulfate treatment. Eur J Endocrinol. 2001;145:799806. doi: org/10.1530/eje.0.1450799.

20. Houstis N, Rosen ED, Lander ES. Reactive oxygen species have a causal role in multiple forms of insulin resistance. Nature. 2006;440:944-8. doi: org/10.1038/nature04634.
21. Ribeiro GS, De Souza DB, Cortez CM, Silva D, Costa WS, Sampaio FJB. Effects of prepubertal corticosterone treatment on urinary bladder. Acta Cir Bras. 2014;29(Suppl 3):55-9. doi: org/10.1590/ S0102-86502014001700011.

22. Van Story-Lewis PE, Tenenbaum HC. Glucocorticoid inhibition of fibroblast contraction of collagen gels. Biochem Pharmacol. 1986;35:1283-6. doi: org/10.1016/0006-2952(86)90272-8.

23. Vilamaior PS, Taboga SR, Carvalho HF. Postnatal growth of the ventral prostate in Wistar rats: a stereological and morphometrical study. Anat Rec A Discov Mol Cell Evol Biol. 2006;288:885-92. doi: org/10.1002/ar.a.20363.

24. Cunha GR, Hayward SW, Wang YZ, Ricke WA. Role of the stromal microenvironment in carcinogenesis of the prostate. Int J Cancer. 2003;107:1-10. doi: org/10.1002/ijc.11335.

25. Scarano WR, Cordeiro RS, Goes RM, Carvalho HF, Taboga SR. Tissue remodeling in guinea pig lateral prostate at different ages after estradiol treatment. Cell Biol Int. 2004;29:778-84. doi: org/10.1210/ endo-88-2-500.

26. Farnsworth WE. Prostate stroma: physiology. Prostate. 1999;38:6072. doi: org/10.1002/(SICI)1097.

\section{Acknowledgement}

To Sidney Pratt, Canadian, BA, MAT (The Johns Hopkins University), RSA diploma (TEFL), for revision of the English.

\section{Correspondence:}

Flávia Cristina Morone Pinto

Núcleo de Cirurgia Experimental, Departamento de Cirurgia

Centro das Ciências da Saúde, UFPE

Av. Prof. Moraes Rego, 1235 Cidade Universitária

50670-901 Recife - PE Brasil

Tel./Fax: (55 81)2126-8519

fcmorone@gmail.com

Received: Feb 10, 2015

Review: Apr 11, 2015

Accepted: May 9, 2015

Conflict of interest: none

Financial sources: National Council for Scientific and Technological Development (CNPq) and Rio de Janeiro Research Foundation (FAPERJ)

${ }^{1}$ Research performed at Urogenital Research Unit, State University of Rio de Janeiro (UERJ), Brazil. Part of PhD degree thesis, Postgraduate Program in Pathophysiology and Surgical Sciences, Urogenital Research Unit, State UERJ. Tutor: Francisco José Barcellos Sampaio. 